\title{
Landscape-scale variation in coral reef community structure in the United States Virgin Islands
}

\author{
Peter J. Edmunds* \\ Department of Biology, California State University, 18111 Nordhoff Street Northridge, CA 91330-8303, USA
}

\begin{abstract}
This study provides a spatial context to a temporal analysis of community structure on shallow reefs along the south shore of St. John, US Virgin Islands. By focusing on 12 to 14 sites stratified by depth $(\sim 10 \mathrm{~m})$ and distributed along the shores of St. John and St. Thomas, surveys in 2011 were used to explore scale-dependency in coral reef community structure by testing for effects of islands, shores (north versus south), and interactions between these 2 factors. Reefs were censused using photoquadrats that were analyzed for percentage cover, first by functional groups (coral, macroalgae, and a combined category [CTB] of crustose coralline algae, algal turf, and bare space) and then by coral genus. Multivariate analyses revealed no differences in coral reef community structure between islands or shores, although reefs differed among sites. Univariate analyses by functional group also revealed differences among sites and 1.9-fold higher coral cover around St. Thomas compared to St. John; there were no differences between shores. The common coral genera displayed unique patterns of variation among sites, with the cover of Orbicella, Montastraea, Porites, and Agaricia differing among sites but not between islands or shores, and the cover of Siderastrea differing between islands in a pattern that varied between shores. Overall, variation among sites in coral reef community structure that overwhelmed differences between islands and shores focuses attention on the importance of testing for mechanisms creating variation at this spatial scale. The present results suggest that priority effects in community succession may represent one mechanism worthy of investigation.
\end{abstract}

KEY WORDS: Coral reef $\cdot$ Scleractinia $\cdot$ Virgin Islands $\cdot$ Ecology $\cdot$ Community

\section{INTRODUCTION}

In his 1989 lecture, Levin (1992) championed scale in ecology and highlighted the limitation of contemporary studies in addressing this topic (see also Wiens 1989). He used 4 paragraphs to discuss the relevance of scale-dependency to climate change science, but this effort could not have foreseen the rapidity with which biomes would register the consequences of global climate change (GCC) (Parmesan \& Yohe 2003) or the extent to which marine systems would be threatened by ocean acidification (OA) (Doney et al. 2009). More than 2 decades later, scale-dependency is playing a central role in understanding the biological consequences of GCC and OA (Chave 2013).
Anthropogenic assaults affecting ecosystem function have attracted intense interest on coral reefs, where decades of change have crystallized as the 'coral reef crisis' (Hughes et al. 2010). The crisis has its origins in the 15th century when explorers reached tropical seas and started to kill large marine vertebrates (Jackson 1997), but the concept gained attention in the 1970s and 1980s when many corals were killed by crown of thorns sea stars (Endean 1973), large storms (Woodley et al. 1981), and emergent diseases (Aronson \& Precht 2001). However, it was not until the late 1980s that the potential for regionalscale coral mortality motivated systematic monitoring to record the changes underway (Bruno \& Selig 2007, Schutte et al. 2010), and by the 21st century, 
such efforts revealed the scope of the coral reef crises (Bellwood et al. 2004). Prior to the late 1980s, coral reef monitoring was informal and ad hoc, but 4 decades later, synthetic analyses of coral reefs can draw upon 1000s of surveys to make a compelling case for region-wide, decadal-scale declines of coral cover (Bruno \& Selig 2007, Schutte et al. 2010, Ateweberhan et al. 2011, Jackson et al. 2014).

Although there is an unprecedented quantity of information on coral reef community structure, much of this comes from one-off, local-scale (i.e. 0 to $20 \mathrm{~km}$; Mittelbach et al. 2001) analyses or surveys over short periods (Schutte et al. 2010). Multiple discrete studies paint a noisy picture of coral reefs over time, but there is potential to alleviate the effects of this variance using meta-analyses (Côté et al. 2005). Regardless of analytical tool, the community structure of coral reefs at the earliest samplings of such temporal compilations often is least well described, yet initial benchmarks strongly influence measurements of trajectories of change. On the Great Barrier Reef for instance, inshore reefs in the 1980s upwardly bias estimates of regional losses of coral cover (Sweatman et al. 2011), with the decision to include them in synthetic summaries having important implications for the estimation of rates of change (Hughes et al. 2011). Likewise, discussions of macroalgal cover on coral reefs are framed by the assertion that macroalgae were uncommon in the 1960s and 1970s (Szmant 2001). Doubts of the veracity of this assertion based on the paucity of data from early decades (Bruno et al. 2013) have challenged the generality that many reefs have transitioned to macroalgal dominance (Mumby et al. 2013).

Long-term monitoring of coral reefs in single locations can overcome some of the aforementioned challenges in detecting changes in community structure, and there are now a large number of programs with this objective (Jackson et al. 2014). However, most studies have yet to attain the longevity at which their potential to provide insightful descriptions of changes can be realized. In cases where decadal-scale analyses are available, it usually is unclear to what extent the trends are relevant to large spatial scales, and the taxonomic resolution remains mostly low (Hughes et al. 2012). Both of these features are unfortunate, because the strength of long-term analyses lies in the detection of changes that have general application, and for low-resolution analyses, the ecological implications of the changes are unlikely to be resolved without taxonomic detail.

The present study employed landscape-scale (20 to $200 \mathrm{~km}$, sensu Mittelbach et al. 2001) sampling as a complement to decadal-scale analysis of coral reefs along $\sim 4 \mathrm{~km}$ of the south coast of St. John, US Virgin Islands (described by Edmunds 2013). Surveys were completed in 2011 on shallow reefs ( 10 m depth) at 12 sites along $\sim 100 \mathrm{~km}$ of the north and south shores of St. John and St. Thomas. The results are used to evaluate the extent to which these coral reefs varied between local and landscape scales (after Mittelbach et al. 2001), with community structure resolved to 3 functional groups and 5 common coral genera. Three hypotheses were tested: (1) there are no differences between St. John and St. Thomas, (2) there are no differences between the north and south shores of the 2 islands, and (3) there is no interactive effect between shores and islands. The test of scaledependency focused on a contrast between islands and shores, based on the rationales that the islands differ in size, human population density (www.census.gov), and degree of protection of natural resources (Rogers et al. 2008) and that the shores differ in hydrodynamic regime and exposure to trade winds (Brown \& Dunne 1980, Rogers et al. 2008). Both islands and shores therefore have the potential to affect coral reef community structure, and rejection of one or more of the aforementioned null hypotheses would support scale-dependency of coral reef community structure.

\section{MATERIALS AND METHODS}

The analysis included sites between Cabritte Horn and White Point (Fig. 1, Table 1) that have been studied annually since 1987 (Edmunds 2013) and 11 sites sampled for the first time in 2011. Two legacy sites, Yawzi Point (Y, $9 \mathrm{~m}$ depth) and Tektite $(\mathrm{T}, 14 \mathrm{~m}$ depth), were chosen in December 1987 to sample reefs with high coral cover and have been censused annually for 27 yr. Six more legacy sites were selected at random between Cabritte Horn and White Point in May 1992 and have been censused annually for $22 \mathrm{yr} ; 5$ sites are at $9 \mathrm{~m}$ depth, and 1 site is at $7 \mathrm{~m}$ depth. Twenty-five years of change in coral reef community structure at the legacy sites are summarized in Edmunds (2013), and here, data from 2011 are placed in a landscape-scale context through a comparison with 11 new sites (at $10 \mathrm{~m}$ depth) sampled in 2011. Together, the aforementioned sites were used to support an experimental design in which 3 sites on each of the north and south shores of St. John and St. Thomas were used to test for differences in benthic community structure between islands and shores. These sites are spread over a linear distance of $\sim 38 \mathrm{~km}$, which embraces $\sim 100 \mathrm{~km}$ of the convoluted shore of St. John and St. Thomas. 


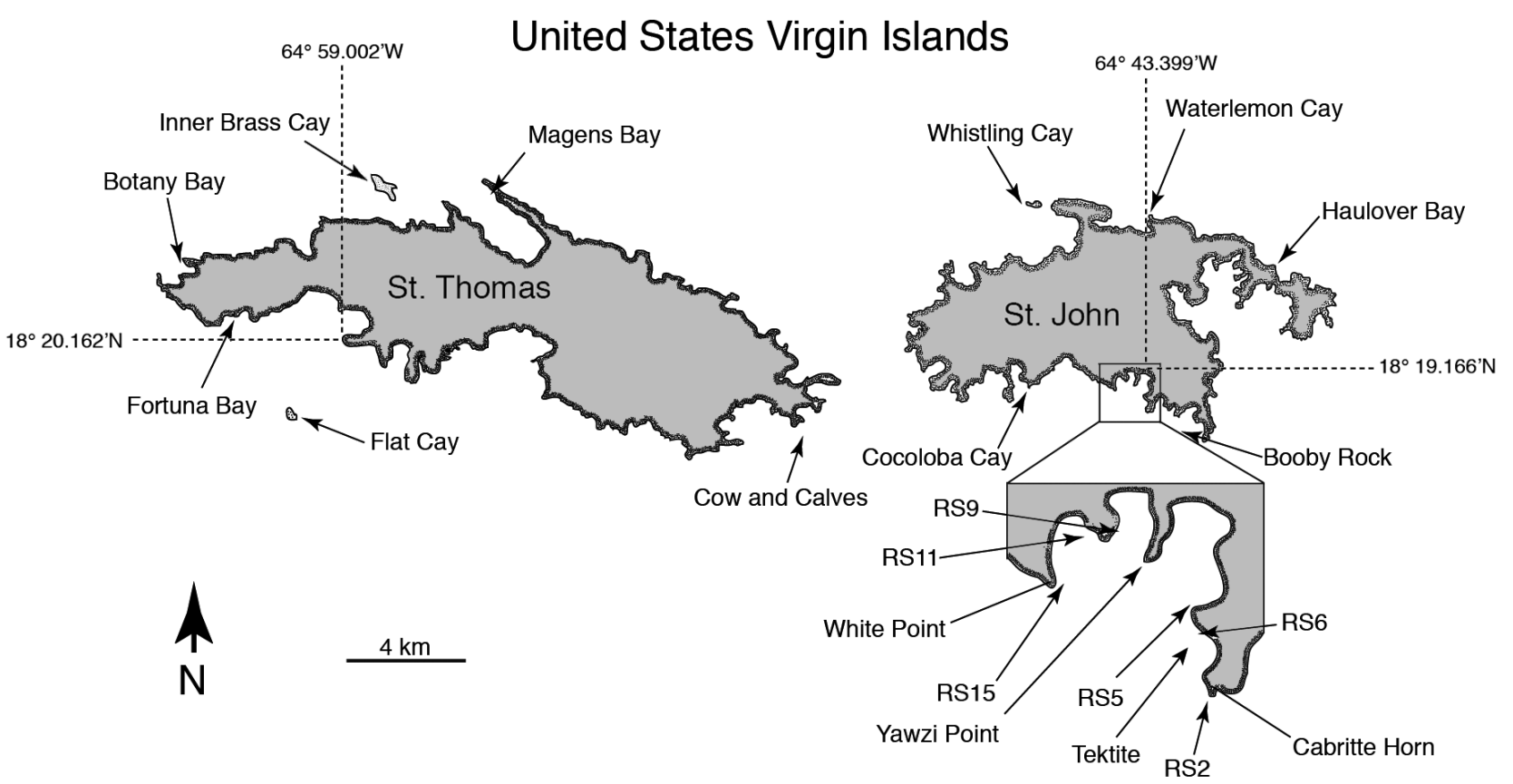

Fig. 1. Study sites around St. John and St. Thomas, US Virgin Islands. This study exploited 8 sites between Cabritte Horn and White Point on the south shore of St. John that have been monitored since as early as 1987 . These were augmented with 11 sites scattered along the shores of St. John and St. Thomas. Between Cabritte Horn and White Point, sites were located at Yawzi Point and Tektite and at 6 locations that were selected randomly in 1992 (RS2-RS15) and analyzed together using a randomly selected subset of 40 quadrats (PRS*). Legacy sites were augmented with Cocoloba Cay and Booby Rock on the south shore of St. John; Haulover Bay, Waterlemon Cay, and Whistling Cay on the north shore of St. John; Magens Bay, Inner Brass Cay, and Botany Bay on the north shore of St. Thomas; and Fortuna Bay, Flat Cay, and Cow and Calves on the south shore of St. Thomas. See Table 1 for depth and coordinates of sites

Yawzi Point and Tektite have been sampled longer and with a sampling strategy that differs from the other sites and therefore were included only to support a qualitative contrast of reef communities on a landscape-scale. The 6 randomly selected sites previously have been combined as the pooled random sites (PRS in Edmunds 2013) to characterize reefs between Cabritte Horn and White Point, and here, the $\sim 240$ photoquadrats recorded at these sites in 2011 were sub-sampled randomly to provide 40 quadrats (hereafter described as PRS*) for use in a balanced statistical design together with the sites sampled only in 2011. The 11 new sites were selected haphazardly in 2011 with the objectives of sampling (1) fringing reef habitats similar to those sampled at the PRS (Edmunds 2013), (2) over the largest possible scale within St. John and St. Thomas, and (3) north and south shores of both islands with 3 sites per shore and consistent spatial coverage along each shore. While sites were not selected randomly, they were chosen without explicit knowledge of the benthic communities in each location, other than knowing that the fringing reef habitat broadly was similar to that sampled at the PRS. The sites were not selected to be 'representative' of reefs along the 4 shores, as this would have confounded the contrast of islands and shores. The sites between Cabritte Horn and White Point are marked permanently (Edmunds 2013), but all other sites are unmarked (Fig. 1).

Benthic community structure was surveyed using photoquadrats recorded with a digital camera (Nikon D70, 6 megapixels) and strobes mounted on a framer that held the camera perpendicular to the substratum. Yawzi Point and Tektite were sampled with $1 \times$ $1 \mathrm{~m}$ photoquadrats placed contiguously along three $10 \mathrm{~m}$ transects (10 photoquadrats transect ${ }^{-1}$ ) that are parallel to one another and at $10 \mathrm{~m}$ (Yawzi Point) or $14 \mathrm{~m}$ (Tektite) depth. All other sites were sampled using $0.5 \times 0.5 \mathrm{~m}$ photoquadrats positioned at 40 points selected at random along a $40 \mathrm{~m}$ transect along the $10 \mathrm{~m}$ depth contour. The reefs in these locations are well-developed fringing reef habitats (Rogers et al. 2008, Smith et al. 2011) and do not develop spur-and-groove structures that would create heterogeneity in the benthic community sampled along a linear transect. The communities sampled were on rock and coral substrata, although occasionally, the random placement of photoquadrats selected pat- 
Table 1. Summary of locations and depths of study sites (Fig. 1). PRS* (pooled random sites) consists of 6 sites selected at random (RS2-15) from which 40 photoquadrats were drawn at random for inclusion in the present study

\begin{tabular}{|llcccc|}
\hline $\begin{array}{l}\text { Island/ } \\
\text { shore }\end{array}$ & \multicolumn{1}{c}{ Site } & Code & $\begin{array}{c}\text { Latitude } \\
\left({ }^{\circ} \mathrm{N}\right)\end{array}$ & $\begin{array}{c}\text { Longitude } \\
\left({ }^{\circ} \mathrm{W}\right)\end{array}$ & $\begin{array}{c}\text { Depth } \\
(\mathrm{m})\end{array}$ \\
\hline $\begin{array}{l}\text { St. John/ } \\
\text { south }\end{array}$ & Yawzi Point & Y & $18^{\circ} 18.912$ & $64^{\circ} 43.500$ & 9 \\
& Tektite & T & $18^{\circ} 18.582$ & $64^{\circ} 43.371$ & 14 \\
& PRS ${ }^{\circ}$ & & & & \\
& RS2 & & $18^{\circ} 18.421$ & $64^{\circ} 43.279$ & 9 \\
& RS6 & & $18^{\circ} 18.657$ & $64^{\circ} 43.312$ & 9 \\
& RS5 & & $18^{\circ} 18.657$ & $64^{\circ} 43.312$ & 9 \\
& RS9 & & $18^{\circ} 19.023$ & $64^{\circ} 43.682$ & 7 \\
& RS11 & & $18^{\circ} 18.996$ & $64^{\circ} 43.793$ & 9 \\
& RS15 & & $18^{\circ} 18.879$ & $64^{\circ} 43.891$ & 9 \\
Cocoloba Cay & CL & $18^{\circ} 18.876$ & $64^{\circ} 45.658$ & 10 \\
Bt. John/ & Booby Rock & BR & $18^{\circ} 18.171$ & $64^{\circ} 45.658$ & 10 \\
north & Haulover Bay & H & $18^{\circ} 21.184$ & $64^{\circ} 40.784$ & 10 \\
& Waterlemon Cay & WL & $18^{\circ} 22.090$ & $64^{\circ} 43.271$ & 10 \\
St. Thomas/ & Whistling Cay & WC & $18^{\circ} 22.168$ & $64^{\circ} 45.689$ & 10 \\
Fouth & Fortuna Bay & FB & $18^{\circ} 20.588$ & $64^{\circ} 1.191$ & 10 \\
& Flat Cay & FC & $18^{\circ} 19.068$ & $64^{\circ} 59.447$ & 10 \\
St. Thomas/ & Cow and Calves & CC & $18^{\circ} 18.246$ & $64^{\circ} 50.892$ & 10 \\
Morth & Magnens Bay & MB & $18^{\circ} 22.904$ & $64^{\circ} 56.423$ & 10 \\
& Botany Bay & BB & $18^{\circ} 21.587$ & $65^{\circ} 2.059$ & 10 \\
& & & & & \\
\hline
\end{tabular}

ches of sand interspersed among corals. As is common on shallow reefs in the Virgin Islands, the benthic communities consisted of a variety of scleractinian and gorgonian corals interspersed with macroalgae, sponges, and rocks coated in algal turf or crustose coralline algae. Sites with the highest cover of scleractinian corals typically consisted of high densities of Orbicella annularis, but all other sites included discrete colonies of Orbicella spp., Montastraea cavernosa, Porites (mostly P. astreoides, P. furcata, and $P$. porites), Siderastrea (mostly $S$. siderea), and Agaricia (mostly A. agaricites and A. humilis) that together covered $\leq 20 \%$ of the reef. Images were analyzed for percentage cover of organisms using CPCe software (Kohler \& Gill 2006) with 200 dots scattered randomly on each image, and analyses were conducted at 2 levels of biological resolution. First, the percentage cover of major functional groups was measured in 3 categories: scleractinians, macroalgae (algae $\geq 1 \mathrm{~cm}$ high, consisting mostly of Halimeda, Lobophora, Padina, and Dictyota), and a combined category of crustose coralline algae, algal turf, and bare space (CTB) that cannot be resolved in planar images (Aronson \& Precht 2000, Edmunds 2013). Second, the percentage cover of scleractinians was measured separately by species, but this was subsequently collapsed to genus because of the low abundance of many species.

\section{Statistical analysis}

To evaluate the efficacy of the sampling regime, plots of the running mean and running SE were examined as a function of the sample size (number of photoquadrats) at each site. These plots were prepared for the 3 functional groups scored within the benthic communities, and convergence to a horizontal asymptote was construed as evidence that further sampling would not appreciably alter the mean or SE (Fig. 2). The percentage cover of benthic categories was compared qualitatively among sites using descriptive statistics and nonmetric multi-dimensional scaling (nMDS; Clarke \& Gorley 2006) to explore patterns in community composition among sites. Photoquadrats were treated as replicates to give a sample size of $\sim 30$ at Yawzi Point and Tektite and $\sim 40$ at all other sites. Descriptive analyses first were conducted using functional groups (i.e. corals, macroalgae, and CTB), and second, genus-level analysis for scleractinians. Site means for descriptive statistics were calculated using raw percentage data for each category.

Ordination plots generated using nMDS were used to visualize patterns of similarity among sites (excluding Yawzi Point and Tektite) using dependent variables (i.e. measures of community composition) that were square-root transformed to provide a conservative adjustment for quantitatively dominant groups (Clarke \& Gorley 2006) and converted to a matrix of Bray-Curtis similarity values. Two nMDS plots were prepared, one based on the percentage cover of the 3 functional groups and one based on the percentage cover by coral genera, and in all cases, analyses were completed using mean cover by site that were calculated using arcsine transformed values. Multiple restarts of 100 iterations were employed for each nMDS until stress stabilized and ordinations were repeatable. In nMDS plots, sites were represented as 'bubbles' scaled to reflect the percentage cover of components of the benthos.

To test the hypotheses that coral reef community structure differed between islands and shores, data were first analyzed with multivariate statistics and then with univariate analyses to better understand the role of each dependent variable in the multivari- 

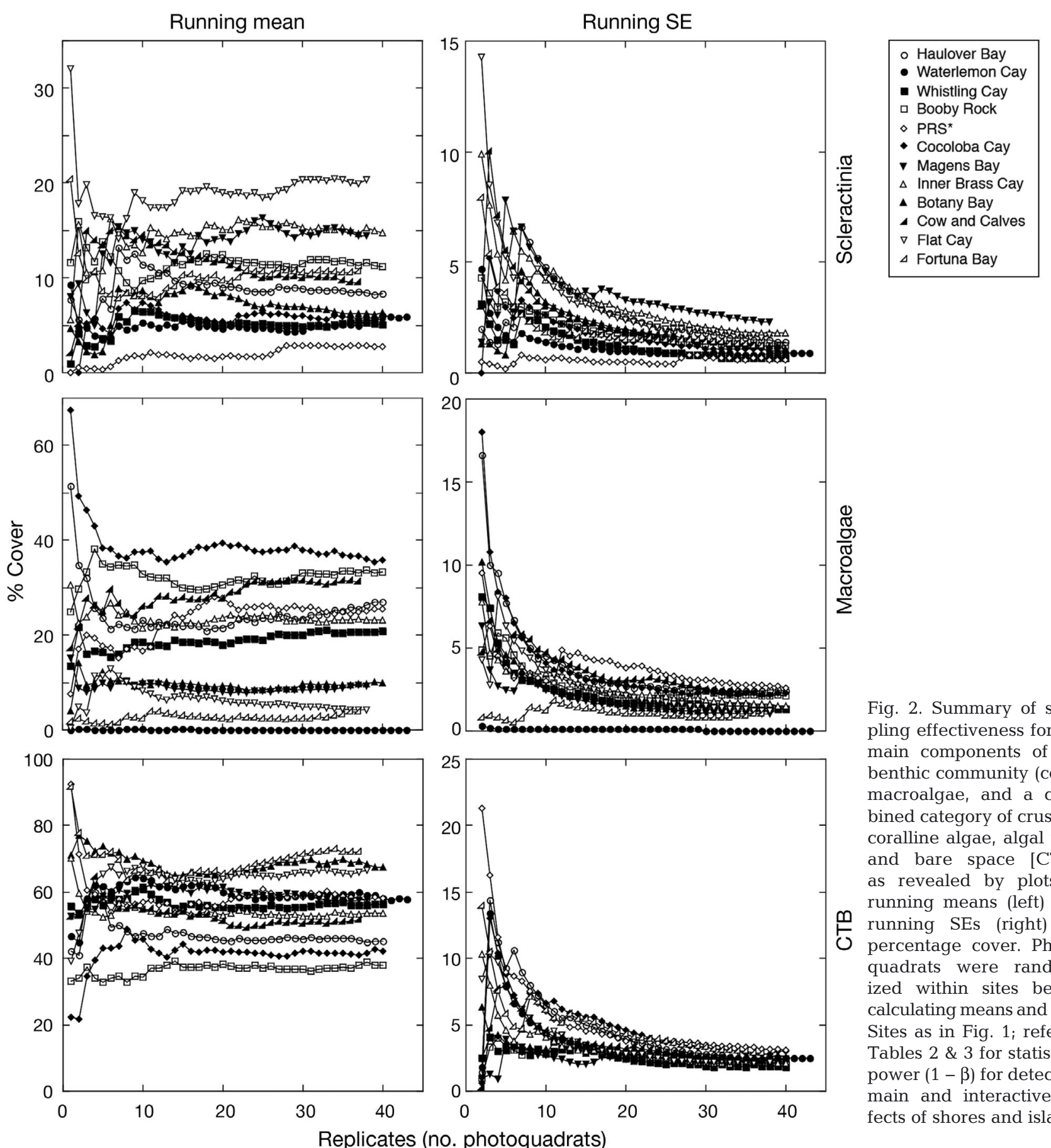

Fig. 2. Summary of sampling effectiveness for the main components of the benthic community (coral, macroalgae, and a combined category of crustose coralline algae, algal turf, and bare space [CTB]) as revealed by plots of running means (left) and $\cong$ running SEs (right) for $\mathcal{U}$ percentage cover. Photoquadrats were randomized within sites before calculating means and SEs. Sites as in Fig. 1; refer to Tables $2 \& 3$ for statistical power $(1-\beta)$ for detecting main and interactive effects of shores and islands

ate analyses. Multivariate analyses were conducted using PERMANOVA (Anderson et al. 2008) in a 3-factor design in which islands and shores were fixed effects, and site (excluding Yawzi Point and Tektite) was a random factor nested within islands and shore. Islands and shores were treated as fixed affects as these contrasts were chosen in the design of the project, whereas sites effectively were random (they were not chosen from a population of possibilities as would be required for a fixed effect). Data (\% cover by photoquadrats) were square-root transformed to adjust for unequal abundance among dependent variables and used to create a matrix using Bray-Curtis similarity. This matrix was used in a PERMANOVA with 999 permutations to test for main and interactive effects using pseudo- $F$ values and permutation $\mathrm{p}$-values $\left(\mathrm{p}_{\text {perm }}\right.$, after Anderson et al. 2008). Two PERMANOVAs were completed, one using the 3 functional groups and the other using all genera of scleractinians encountered. 
Following the multivariate analyses, univariate ANOVAs were employed in which islands and shores were fixed effects, and sites (excluding Yawzi Point and Tektite) were a random effect nested in shores and islands. Photoquadrats were treated as replicates, and the dependent variables were arcsine-transformed percentage cover values for the 3 functional groups, as well as 5 dominant coral genera (Montastraea [only M. cavernosa; Budd et al. 2012], Orbicella [formerly Montastraea annularis complex; Budd et al. 2012], Porites, Siderastrea, and Agaricia). To explore variation among sites, separate univariate ANOVAs were used to compare dependent variables among sites with multiple contrasts explored using a post hoc Bonferonni procedure. Analyses were completed for the 3 functional groups and the 5 common coral genera (Montastraea, Orbicella, Porites, Siderastrea, and Agarica). Data were tested for confirmation to the normality and homoscedasticity assumptions of ANOVA through graphical analysis of the residuals. Retrospective power $(1-\beta)$ was calculated according to Zar (2010) using an arbitrary effect size of $1 \%$.

Multivariate statistics were completed using Primer-E (v. 6) (Clarke \& Gorley 2006) with the PERMANOVA+ add-on (v. 1.0.6) (Anderson et al. 2008), and univariate statistics were completed using Systat 11 (Systat Software), in both cases in a Windows environment.

\section{RESULTS}

\section{Descriptive statistics}

In 2011, the 12 sites at the core of this analysis, as well as the 2 legacy sites included for reference (Yawzi Point and Tektite), differed in cover of functional groups and coral genera (Fig. 3A-C). Tektite had $\sim 25 \%$ coral cover, most of which was Orbicella annularis; a few sites had 10 to $15 \%$ coral cover, but most had relatively little coral. At most sites, nearly a third of the reef was covered by macroalgae, although macroalgae was virtually absent at Waterlemon Cay, and at all sites, the dominant functional group was CTB. Coral cover was dominated by 5 genera, with Orbicella conspicuous (i.e. $>2 \%$ cover) at 4 sites, Montastraea conspicuous at 1 site, Porites conspicuous at 4 sites, and Siderastrea conspicuous at 5 sites. The cover of Agaricia was $<2 \%$ at all sites.

Overall, mean coral cover varied 10-fold from $2.7 \pm$ $0.7 \%$ at the PRS* to $27.8 \pm 2.0 \%$ at Tektite, macroalgae varied 326 -fold from $0.1 \pm<0.1 \%$ at Water- lemon Cay to $35.8 \pm 2.3 \%$ at Cocoloba Cay, and CTB varied 1.9-fold from $38.1 \pm 2.4 \%$ at Booby Rock to $72.0 \pm 2.9 \%$ at Fortuna Bay. Exclusion of Yawzi Point and Tektite from this contrast changed the range of scleractinian cover (but not macroalgae or CTB), which then varied 7.6-fold from $2.7 \pm 0.7 \%$ at the PRS $^{*}$ to $20.4 \pm 1.7 \%$ at Flat Cay. Ordination plots generated by nMDS applied to the cover of the 3 functional groups at the 12 equivalent sites (Fig. 3D-F) revealed differences among sites, the absence of clustering related to shores, and weak clustering that separated St. John and St. Thomas.

Mean coral cover at the 12 equivalent sites was $\leq 20.4 \%$, and the cover of most species was low. Overall, representatives of 16 genera of corals (pooled among sites) representing 25 species were found, of which the most common (i.e. $\geq 0.2 \%$ mean cover) were Orbicella annularis, O. franksi, Agaricia agaricites, Colpophyllia natans, Diploria strigosa, Montastraea cavernosa, Meandrina meandrites, Porites astreoides, $P$. porites, $P$. furcata, and Siderastrea siderea. Acropora palmata was not seen in the 473 photoquadrats from 2011, although large colonies were seen in the vicinity of some of the sites, notably Haulover Bay and Flat Cay. When collapsed by genus, mean cover ( $\mathrm{n}=473$ quadrats) ranged from $2.116 \%$ (Orbicella) to $0.002 \%$ (Manicina), and of the 16 genera encountered, 5 supported meaningful analyses based on mean percentage cover: Montastraea (1.6\% cover), Orbicella (2.1\% cover), Porites (1.5\% cover), Siderastrea (2.2\% cover), and Agaricia ( $0.5 \%$ cover) (all $n=473$ quadrats) (Fig. 4A-E). The ordination plots generated by nMDS utilizing genuslevel cover revealed differences among sites but similarity of the coral community structure between islands and shores (based on the absence of island- or shore-based clusters) (Fig. 4F-J).

\section{Multivariate inferential analysis}

Multivariate coral reef community structure based on the percentage cover of the 3 functional groups did not vary between islands (PERMANOVA, pseudo- $F=2.050$, df $=1,8, p_{\text {perm }}=0.156$ ) or shores (pseudo- $F=0.471$, df $=1,8, p_{\text {perm }}=0.626$ ) and was unaffected by the interaction between those 2 factors (pseudo- $F=1.938$, df $=1,8, p_{\text {perm }}=0.184$ ), but differed among sites (pseudo- $F=37.575$, df $=8,461$, $\mathrm{p}_{\text {perm }}=0.001$ ). Likewise, multivariate coral community structure based on the percentage cover of coral genera did not vary between islands (pseudo- $F=$ $\left.1.011, \mathrm{df}=1,8, \mathrm{p}_{\text {perm }}=0.408\right)$ or shores $($ pseudo $-F=$ 

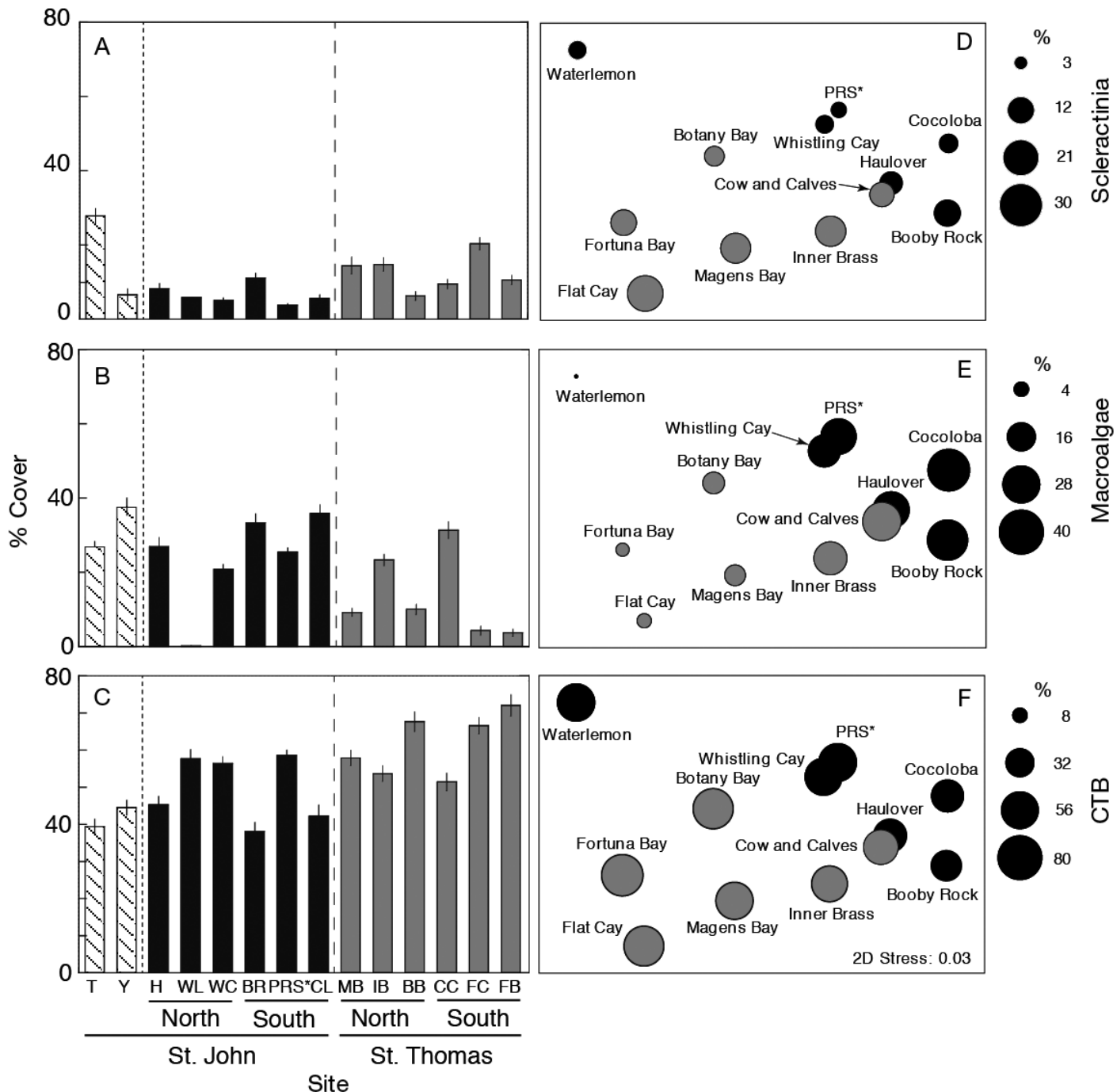

Fig. 3. Benthic community structure on reefs in St. John and St. Thomas in 2011. (A-C) Percentage cover $($ mean $\pm \mathrm{SE}, \mathrm{n}=30$ at $\mathrm{Y}$ and $\mathrm{T}, \mathrm{n}=\sim 40$ at all other sites) of coral (pooled among taxa), macroalgae, and CTB, respectively, at 6 sites around St. Thomas and 8 sites around St. John, with site codes as in Table 1. All sites are at 7 to $10 \mathrm{~m}$ depth, except Site T (14 m) and 1 site in the PRS* group. (D-F) Ordination plots generated using non-metric multi-dimensional scaling (nMDS) displaying the relationships among 12 sites (excluding Y and T) based on the percentage cover of coral, macroalgae, and CTB. The diameters of the bubbles on each nMDS plot are scaled to the percentage cover of (D) coral, (E) macroalgae, and (F) CTB

2.223, df $\left.=1,8, \mathrm{p}_{\text {perm }}=0.093\right)$, and was unaffected by the interaction between the two (pseudo- $F=1.488$, $\left.\mathrm{df}=1,8, \mathrm{p}_{\text {perm }}=0.202\right)$, but differed among sites (pseudo- $F=11.936, \mathrm{df}=8,461, \mathrm{p}_{\text {perm }}=0.001$ ).

\section{Univariate inferential statistics}

The cover of the 3 function groups differed among sites (ANOVA, Table 2). While neither macroalgae nor CTB differed between islands ( $p \geq 0.053$ ), coral cover differed between islands $(p=0.045)$ and was higher on St. Thomas compared to St. John. When averaged among sites within islands, mean $( \pm 1 \mathrm{SE})$ coral cover on St. Thomas $(12.7 \pm 2.0 \%)$ was 1.9 -fold higher than on St. John $(6.6 \pm 1.1 \%)(n=6$ sites $)$. When site effects were evaluated independent of islands and shores, sites differed significantly for coral $(F=16.033$, df $=11,461, \mathrm{p}<0.001)$, macroalgae $(F=82.407, \mathrm{df}=11,461, \mathrm{p}<0.001)$ and CTB $(F=$ 16.919, df $=11,461, \mathrm{p}<0.001)$. Post hoc Bonferroni contrasts revealed where the site effects were strongest for each functional group (Fig. 5A-C). Coral cover was significantly higher at Flat Cay, Inner Brass, and Magens Bay than at most other sites and significantly lower at PRS * compared to many other sites. The cover of macroalgae was significantly different among most pairs of sites $(63 \%$ of the con- 

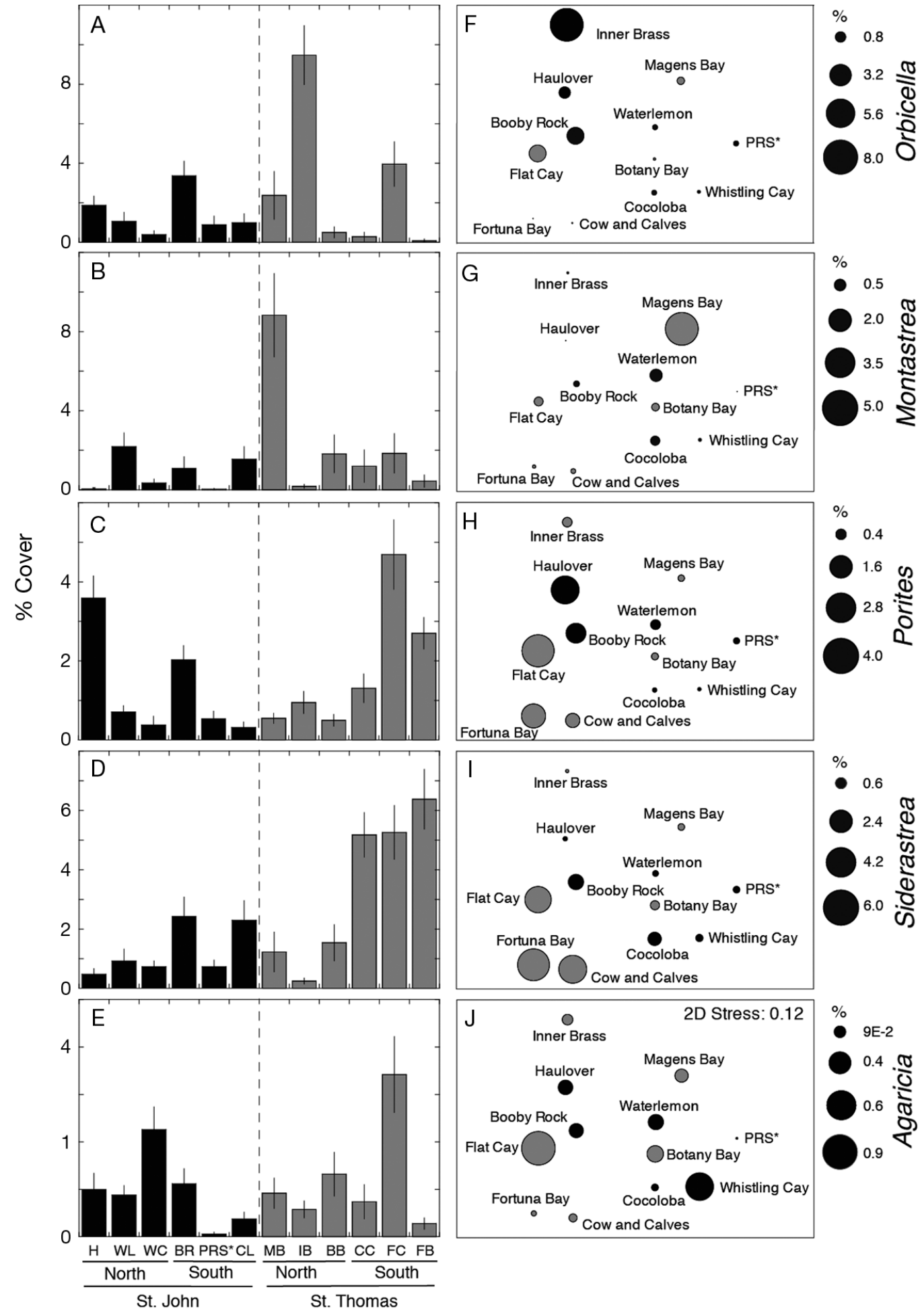

Site

Fig. 4. Genus-level coral community structure on reefs in St. John and St. Thomas in 2011. (A-E) Percentage cover (mean \pm $\mathrm{SE}, \mathrm{n}=37$ to 43 photoquadrats transect ${ }^{-1}$ ), calculated from untransformed values of the 5 dominant genera (site codes as in Table 1). (F-J) Ordination plots generated using non-metric multi-dimensional scaling displaying the relationship among sites based on the percentage cover (site means from transformed data) of coral genera (Montastraea, Orbicella, Agaricia, Colpophyllia, Dendrogyra, Dichoecoenia, Diploria, Eusmilia, Favia, Madracis, Meandrina, Porites, Stepahnocoenia, Siderastrea, Manicina, and Mycetophyllia), with the diameter of bubbles scaled to the percentage cover of the dominant genera:

(F) Orbicella, (G) Montastraea, (H) Porites, (I) Siderastrea, and (J) Agaricia 
Table 2. Results of statistical analyses of benthic community structure on St. John and St. Thomas. Three-way nested ANOVAs were used to compare islands (fixed effect), shores (north vs. south, fixed effect), and sites (random effect nested in islands and shores), using photoquadrats as statistical replicates $\left(\mathrm{n}=\sim 40 \mathrm{site}^{-1}\right)$. The percentage cover of coral, macroalgae, and CTB were used as dependent variables and were arcsine transformed prior to analysis. Significant values in bold

\begin{tabular}{|llrrrrr|}
\hline $\begin{array}{c}\text { Dependent } \\
\text { variable }\end{array}$ & \multicolumn{1}{c}{ Source } & df & MS & $F$ & p & Power \\
\hline Coral & Islands & 1 & 1.404 & 5.619 & $\mathbf{0 . 0 4 5}$ & $\sim 0.84$ \\
& Shore & 1 & 0.029 & 0.117 & 0.741 & $\sim 0.84$ \\
& Island $\times$ Shore & 1 & 0.107 & 0.430 & 0.531 & $\sim 0.35$ \\
& Site(Island $\times$ Shore) & 8 & 0.250 & 12.460 & $<\mathbf{0 . 0 0 1}$ & \\
& Error & 461 & 0.020 & & & \\
Macroalgae & Islands & 1 & 2.124 & 1.308 & 0.286 & $\sim 0.30$ \\
& Shore & 1 & 0.900 & 0.554 & 0.478 & $\sim 0.30$ \\
& Island $\times$ Shore & 1 & 2.981 & 1.836 & 0.212 & $<0.30$ \\
& Site(Island $\times$ Shore) & 8 & 1.623 & 76.851 & $<\mathbf{0 . 0 0 1}$ & \\
CTB & Error & 161 & 0.021 & & & \\
& Islands & 1 & 1.926 & 5.129 & 0.053 & $\sim 0.70$ \\
& Shore & 1 & 0.027 & 0.072 & 0.796 & $\sim 0.70$ \\
& Island $\times$ Shore & 1 & 0.363 & 0.967 & 0.354 & $\sim 0.25$ \\
& Site(Island $\times$ Shore) & 8 & 0.376 & 13.182 & $<\mathbf{0 . 0 0 1}$ & \\
& Error & 461 & 0.028 & & & \\
\hline
\end{tabular}

Porites, cover was higher at Haulover Bay, Booby Rock, Flat Cay, and Fortuna Bay than at most other sites; for Siderastrea, cover was higher at Cow and Calves, Flat Cay, and Fortuna Bay than at most other sites; and for Agaricia, cover was higher at Flat Cay and Whistling Cay than at most other sites.

\section{DISCUSSION}

\section{Overview}

This study was designed to complement a 27 yr analysis of coral reefs in St. John (Edmunds 2013) and to contribute to a larger effort describing the coral reefs of the US Virgin Islands since the 1950s (Rogers et al. 2008, Smith et al.

trasts), and CTB differed among nearly half the contrasts among sites (41\% of the contrasts) and was highest at Fortuna Bay and lowest at Booby Rock, Cocoloba Cay, and Haulover Bay.

When coral cover was separated by genus, the cover of 4 genera differed among sites, but not islands, shores, or the interaction between these factors (Table 3). Siderastrea showed a different pattern, with no variation in cover among sites, but differences between islands that varied between shores (i.e. the island $\times$ shore interaction was significant). Siderastrea was more common on the south shores of St. John and St. Thomas, but the effect relative to the north shore was more pronounced on St. Thomas (Fig. 4D). Site effects (independent of island and shores) were significant for Montastraea $(F=9.981$, $\mathrm{df}=11,461, \mathrm{p}<0.001)$, Orbicella $(F=19.713, \mathrm{df}=11$, 461, p < 0.001), Porites $(F=20.207$, df $=11,461, \mathrm{p}<$ $0.001)$, Siderastrea $(F=18.636, \mathrm{df}=11,461, \mathrm{p}<$ 0.001), and Agaricia ( $F=6.829$, df $=11,461, \mathrm{p}<$ 0.001). Post hoc Bonferroni contrasts among pairs of sites for 4 genera revealed significant contrasts for 19 to $39 \%$ of the cases, although cover of the fifth genus (Montastraea) differed among $60 \%$ of the site contrasts (Fig. 5D-H). For Orbicella, cover was higher at Inner Brass, Flat Cay, Booby Rock, and Magens Bay compared to most other sites; for Montastraea, most site contrasts were significant due to strong within island variation, although cover at Magens Bay was higher than any other location; for
2011, 2013, Edmunds 2013, Friedlander et al. 2013). It is not the only project addressing landscape-scale variation in coral reefs in this region (e.g. Rogers \& Miller 2006, Smith et al. 2011, 2013, Friedlander et al. 2013), but it is unusual in the extent to which it can be used in the future to support spatio-temporal contrasts through comparison with decadal-scale monitoring conducted with similar methods, standardized by depth. This potential has yet to be fully realized for St. John and St. Thomas (although the best contrasts are reported by Rogers \& Miller 2006, Smith et al. 2011, 2013, and Friedlander et al. 2013), but by focusing on spatial variation at $10 \mathrm{~m}$ depth in 1 year, the present analysis tested 3 hypotheses that are relevant to achieving this potential.

First, tests for differences between islands (Hypothesis 1) revealed that overall coral reef community structure was indistinguishable between St. Thomas and St. John. However, univariate analyses revealed differences between islands in coral cover, with St. Thomas having nearly twice as much coral as St. John, and much of this attributed to Siderastrea. Second, tests for shore effects (Hypothesis 2) revealed no differences in overall coral reef community structure or any component of the benthic community, except for Siderastrea, which was more abundant on south shores. Third, tests for interactive effects of shores and islands (Hypothesis 3) revealed no differences in overall coral reef community structure or any component of the benthic community, 

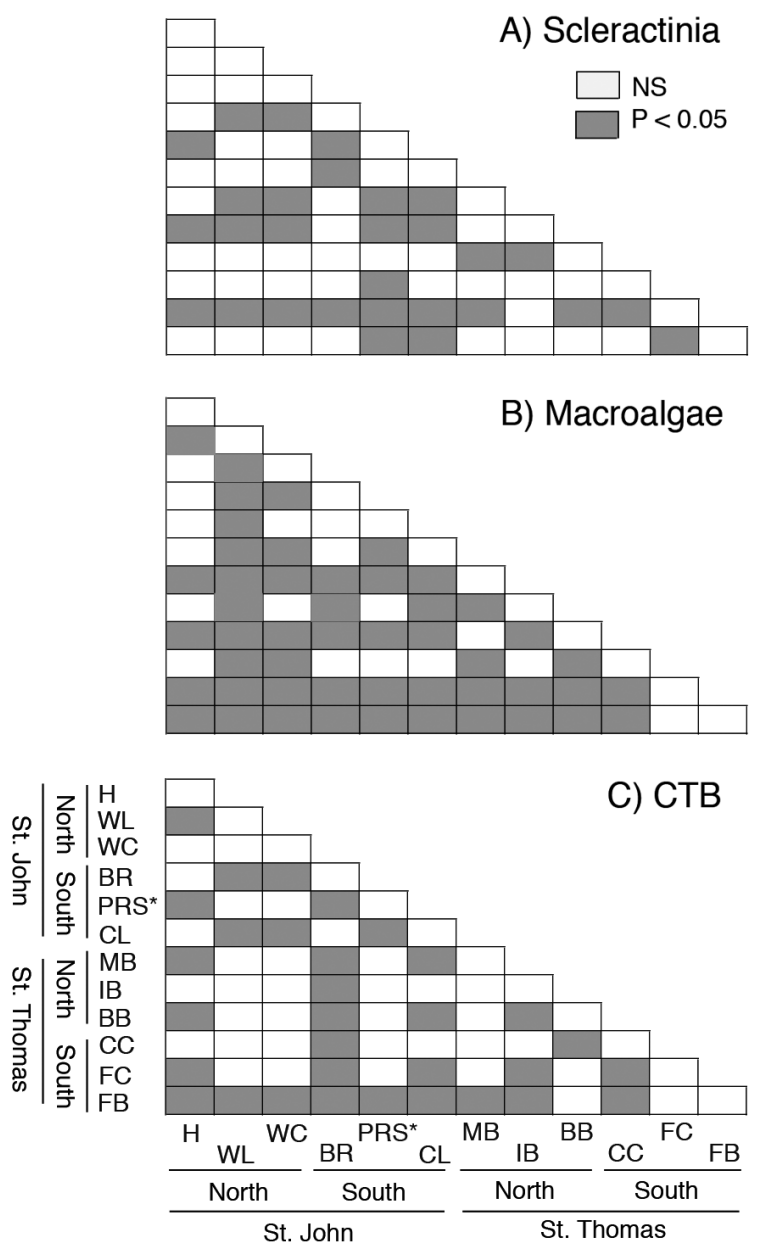

Fig. 5. Summary of post hoc, multiple contrasts among sites (site codes in Table 1) of (A-C) 3 functional groups and (D-H) 5 dominant genera following univariate contrasts of each dependent variable among sites. Sites, shore, and islands are listed only on bottom panels, with sites in the same sequence as in Figs. $3 \& 4$. Post hoc contrasts were conducted with a Bonferonni procedure, and significant differences $(p<$ 0.05) are shaded

except Siderastrea for which the discrepancy between shores was accentuated on St. Thomas. Finally, the largest source of variation in coral reef community structure was site, with this effect involv-
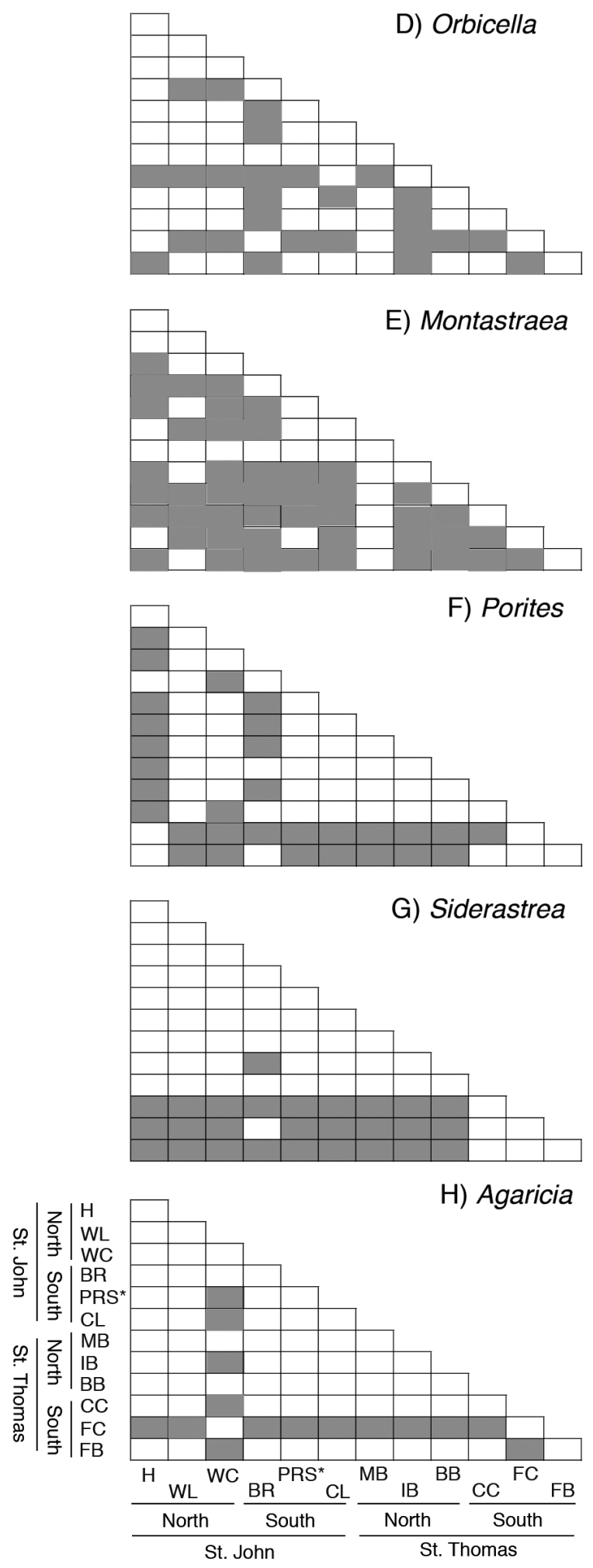

ing both multivariate and univariate aspects of benthic community structure. Individual sites had unique coral communities defined in part by the percentage cover of the most common coral genera. 
Table 3. Results of statistical analyses of coral community structure on St. John and St. Thomas. Three-way nested ANOVAs were used to compare islands (fixed), shores (north versus south, fixed), and sites (random, nested in islands and shores), using photoquadrats as statistical replicates $\left(\mathrm{n}=\sim 40\right.$ site $\left.^{-1}\right)$. The percentage coverage of the 5 dominant genera were used as dependent variables and were arcsine transformed prior to analysis. Significant values in bold

\begin{tabular}{|c|c|c|c|c|c|c|}
\hline $\begin{array}{l}\text { Dependent } \\
\text { variable }\end{array}$ & Source & df & MS & $F$ & $\mathrm{p}$ & Power \\
\hline \multirow[t]{5}{*}{ Orbicella } & Islands & 1 & 0.046 & 0.170 & 0.691 & $\sim 0.76$ \\
\hline & Shore & 1 & 0.060 & 0.218 & 0.653 & $\sim 0.76$ \\
\hline & Island $\times$ Shore & 1 & 0.219 & 0.791 & 0.400 & $\sim 0.33$ \\
\hline & Site(Island $\times$ Shore) & 8 & 0.276 & 23.569 & $<0.001$ & \\
\hline & Error & 461 & 0.012 & & & \\
\hline \multirow[t]{5}{*}{ Montastraea } & Islands & 1 & 0.105 & 0.757 & 0.410 & $\sim 0.97$ \\
\hline & Shore & 1 & 0.093 & 0.671 & 0.436 & $\sim 0.97$ \\
\hline & Island $\times$ Shore & 1 & 0.089 & 0.637 & 0.448 & $\sim 0.58$ \\
\hline & Site(Island $\times$ Shore) & 8 & 0.139 & 11.088 & $<0.001$ & \\
\hline & Error & 461 & 0.013 & & & \\
\hline \multirow[t]{5}{*}{ Porites } & Islands & 1 & 0.051 & 0.490 & 0.504 & $>0.98$ \\
\hline & Shore & 1 & 0.149 & 1.428 & 0.266 & $>0.98$ \\
\hline & Island $\times$ Shore & 1 & 0.372 & 3.560 & 0.096 & $\sim 0.71$ \\
\hline & Site(Island $\times$ Shore) & 8 & 0.104 & 16.642 & $<0.001$ & \\
\hline & Error & 461 & 0.006 & & & \\
\hline \multirow[t]{5}{*}{ Siderastrea } & Islands & 1 & 0.444 & 22.767 & 0.001 & $>0.99$ \\
\hline & Shore & 1 & 1.194 & 61.215 & $<0.001$ & $>0.99$ \\
\hline & Island $\times$ Shore & 1 & 0.406 & 20.794 & 0.002 & $>0.90$ \\
\hline & Site(Island $\times$ Shore) & 8 & 0.020 & 1.867 & 0.063 & \\
\hline & Error & 461 & 0.010 & & & \\
\hline \multirow[t]{5}{*}{ Agaricia } & Islands & 1 & 0.001 & 0.048 & 0.832 & $>0.99$ \\
\hline & Shore & 1 & 0.019 & 0.737 & 0.416 & $>0.99$ \\
\hline & Island $\times$ Shore & 1 & 0.044 & 1.733 & 0.224 & $>0.90$ \\
\hline & Site(Island × Shore) & 8 & 0.025 & 7.138 & $<0.001$ & \\
\hline & Error & 461 & 0.004 & & & \\
\hline
\end{tabular}

Therefore, the community structure of the shallow coral reefs around St. John and St. Thomas was largely scale independent. The strong variation among sites did not indicate scale-dependency because the form and direction of variation was inconsistent, and it was measured at the same local scale at all sites. There was, however, evidence of scale dependency in coral cover that differed predictably between islands, and Siderastrea cover that was greater on south shores.

The decadal-scale analysis of Edmunds (2013) focused on reefs between Cabritte Horn and White Point. One site was an Obicella annularis-dominated habitat at $14 \mathrm{~m}$ depth (Tektite), one was an O. annularis-dominated habitat at $9 \mathrm{~m}$ depth (Yawzi Point), and 6 sites sampled a near-shore habitat at 7 to $9 \mathrm{~m}$ depth where $O$. annularis has remained uncommon since 1992. The near-shore sites were randomly selected in 1992, and Edmunds (2013) combined these sites as the 'pooled random sites' (PRS) to describe this fringing reef habitat. The present study sampled a habitat similar to that encountered at the PRS and used a sampling regime supporting a balanced contrast between islands and shores that included a random subset of the PRS data from 2011. The reefs censused only in 2011 were similar to those at the PRS, although Inner Brass included patches of Orbicella annularis comparable to those at $9 \mathrm{~m}$ depth at Yawzi Point (Edmunds 2013). In evaluating the ecological significance of the present spatial analysis, 3 findings from this temporal analysis are particularly relevant.

First, in 2011, coral reef community structure differed among habitats in the temporal analysis, with a mean coral cover of $3.8 \%$ at PRS, $6.7 \%$ at Yawzi Point, and $28.6 \%$ at Tektite, and macroalgae covered $25.4 \%$ to $37.7 \%$ of the benthos. Orbicella annularis accounted for 77 to $78 \%$ of the coral cover at Yawzi Point and Tektite but was uncommon at the PRS, where the dominant genera were Montastraea (0.9\% cover), Siderastrea $(0.8 \%)$, Porites $(1.0 \%)$, Diploria (0.2\%), and Agaricia (0.1\%). Therefore, similar to the present analysis, the long-term analysis reveals spatial variation in coral reef community structure on a scale of kilometers. Second, between 1987 and 2011, mean coral cover at Yawzi Point declined from 44.6 to $6.7 \%$; at Tektite, it increased from 32.2 to $48.8 \%$ in 2002 but then declined to $28.6 \%$ in 2011 , and at the PRS, it remained between $2.8 \%$ (2008) and $4.5 \%$ (1993) from 1992 to 2011. As trajectories of change in coral community structure differed among nearby habitats exposed to similar physical conditions, community dynamics were not solely dependent on spatially and temporally coherent disturbances. Therefore, the ways in which areas of reef responded to common biological and physical conditions in the long-term analysis contributed to spatial variation in coral reef community structure similar to that described in the present analysis. Finally, annual surveys of juvenile coral abundance $(\leq 4 \mathrm{~cm}$ diameter) revealed asynchronous variation for 6 genera that included multiple and successive increases and decreases. Juvenile corals are the products of recruit- 
ment and post-settlement success over several years, and variation in their density reflects changing capacities of coral populations to grow. Therefore, the long-term analysis demonstrates that variation in densities of juvenile corals could contribute to spatial variability in coral reef community structure similar to that described in the present study. Below, these 3 findings are used to enhance the interpretation of the present spatial analysis.

\section{Variation between islands and shores (Hypotheses 1 to 3)}

The 3 hypotheses framing the present analysis were not rejected with multivariate analyses of coral reef community structure and were rejected for only 2 of 8 categories of benthic groups analyzed with univariate procedures. Since north and south shores of St. John and St. Thomas differ in hydrodynamic regime associated with oceanic swells driven by trade winds (Brown \& Dunne 1980, Rogers et al. 2008), and St. John and St. Thomas differ in human population sizes (4197 on St. John versus 51181 on St. Thomas in 2010 [www.census.gov]) and in the proportion of land and sea within protected areas (more on St. John versus St. Thomas; Rogers et al. 2008), it was surprising to detect so little variation between islands and shores and to find higher coral cover around St. Thomas versus St. John. Identifying the causes of these patterns will require further hypothesis testing, but the patterns themselves demonstrate that the assumption that coral reefs would be 'better' on a smaller island with fewer people and proportionally more land and sea within protected areas (i.e. St. John) is incorrect (cf. Sandin et al. 2008).

Clearly, the efficacy of the experimental design in the present analysis is critical in evaluating the biological significance of the results. Relative to recent studies of coral reefs in this region, sites in the present analysis were quantified with a high degree of precision - arising both from the number of replicate photoquadrats $\left(\sim 40\right.$ site $\left.^{-1}\right)$ and the number of decisions (200) associated with identifying the benthos in each image - but the number of sites surveyed was limited. For example, Friedlander et al. (2013) drew upon an extensive data set from numerous sites in the US Virgin Islands (http://www8.nos.noaa.gov/ bpdmWeb) to describe benthic communities on reefs around St. John, which was based on 677 sites in water $\leq 30 \mathrm{~m}$ deep from 2001 to 2009 . Their analysis reported a grand mean coral cover of $4.9 \pm 6.4 \%$ ( $\pm 1 \mathrm{SD})$ on hard surfaces, with coral cover differing among reefs inside versus outside the VI National Park. Their habitat maps, however, reveal a high degree of homogeneity among sites in cover of major components of the benthos, although the resolution for percentage cover was relatively coarse. In a separate study, Smith et al. (2011) described benthic communities on 12 reefs at 6 to $20 \mathrm{~m}$ depth around St. Thomas. Over 5 to 11 years between 2001 and 2011, a variety of trends for coral reef community structure were recorded, with strong differences among sites in the final year analyzed (2011). Coral cover declined on 5 reefs, increased on 1 reef, and remained virtually unchanged on 6 reefs as well as on an additional reef at $7 \mathrm{~m}$ depth off St. John. In 2011, mean coral cover ranged from $\sim 4 \%$ at South Water (20 m depth) to $\sim 34 \%$ at Brewers Bay $(6 \mathrm{~m}$ depth). Although the present study uses fewer sites than Friedlander et al. (2013) or Smith et al. (2011), these studies do not make a compelling case that the present study under-sampled for the purpose of comparing between islands and shores at a single depth. Indeed, given the differences in methods among these studies, notably with the results of Friedlander et al. (2013) and Smith et al. (2011) coming from a range of depths and utilizing dissimilar means of assessing benthic cover, it is not possible to conclude that the results for benthic community structure are inconsistent among studies. Further, as the power for detecting main effects in the univariate analyses in the present study was high for most dependent variables (except macroalgae), the variation (or similarity) of benthic community structure between islands and shores is likely to be biologically meaningful, at least for near-shore reefs at $\sim 10 \mathrm{~m}$ depth.

The present study shows that coral reefs at $\sim 10 \mathrm{~m}$ depth differed among sites in 2011, but it cannot demonstrate that these differences have persisted over multiple years. Decadal-scale analyses of coral reefs around St. John and St. Thomas demonstrate that such site effects can be persistent (Smith et al. 2011, Friedlander et al. 2013), but since at least some of these reefs have changed over time (Rogers \& Miller 2006, Smith et al. 2011), there is little reason to expect that historic spatial variation in coral reef community structure would be similar to that observed on contemporary reefs. Over longer periods, it is even less likely that contemporary coral reef community structure, or its spatial variation, is representative of what once was found on the same reefs (Jackson 1997). The Caribbean-wide mortalities of Acropora spp. by white band disease in the early 1980s (Aronson \& Precht 2001) and the sea urchin Diadema antillarum by an unknown pathogen in 
1983 (Lessios et al. 1984), 3 major coral bleaching events in 1987, 1998, and 2005 (Glynn 1993, Aronson et al. 2002, Smith et al. 2013), and increasing human population size and terrestrial development provide 4 examples of disturbances causing contemporary Caribbean reefs to differ markedly from those that would have been found $>40 \mathrm{yr}$ ago. Together, the combined effects of such disturbances favor biotic homogenization of coral reefs (Hoegh-Guldberg et al. 2007, Burman et al. 2012), notably with increased abundances of 'weedy' corals (Green et al. 2008), and this could explain why aspects of the shallow reefs of St. John and St. Thomas now statistically are indistinguishable. Presumably, spatial variation in the impacts of these disturbances around St. John and St. Thomas could create the island- and shore-based effects for the cover of coral and Siderastrea, respectively, but without more detailed information about site-specific community dynamics these possibilities cannot be resolved.

\section{Potential mechanisms of spatial variation}

Local-to-landscape scale patchiness in coral reefs is common (Done 1982, Rogers 1993, Hughes et al. 2012), and many reefs differ over several kilometers in percentage cover of corals, macroalgae, CTB, and select coral genera (Done 1982, Bruno \& Selig 2007, Schutte et al. 2010, and many references therein). Although well documented, understanding of the causes of this variation is incomplete, and often it is explained as a product of a mosaic of reef patches differing in time since the last disturbance (Karlson \& Hurd 1993, Done 1999). While such an explanation can account for some differences among nearby reefs, it does not explicitly consider the roles of mortality, growth, larval supply, settlement success, or post-settlement performance of corals in driving variation in coral community structure (Hughes et al. 2012). Such processes can create spatial heterogeneity in coral community structure through densitydependent settlement (Vermeij \& Sandin 2008), episodic high recruitment reminiscent of masting (Edmunds \& Elahi 2007), variation in post-settlement success, or the delivery of larvae to vacant space suitable for settlement (Sutherland 1974). Recent evidence suggests that the aforementioned processes can function as flexible (rather than rigid) assembly rules driving large-scale spatial variation in coral community structure (Hughes et al. 2012).

In the present study, the strong differences among sites in coral reef community structure included large effects for individual coral genera. For example, Montastraea (M. Cavernosa) occupied $8.8 \%$ of the benthos at Magens Bay but only $0.2 \%$ at Inner Brass $\sim 4 \mathrm{~km}$ away, Orbicella occupied $9.5 \%$ of the benthos at Inner Brass yet only $0.3 \%$ at Cow and Calves $\sim 15 \mathrm{~km}$ away, and Agaricia occupied $1.1 \%$ of the benthos at Whistling Cay but $<0.1 \%$ at PRS $\sim 7 \mathrm{~km}$ away (Fig. 3). These patterns focus attention on at least 2 hypotheses that could account for variation over several kilometers in coral reef community structure. First, it is possible that the differences among sites in the abundance of coral genera represent the spatial sampling of communities at different stages of recovery following disturbances, with the differential abundance of genera reflecting deterministic successional stages of community development (sensu Ricklefs 1990). While there is evidence that changes in coral reef communities can be interpreted in a successional context (Connell \& Slatyer 1977, Karlson \& Hurd 1993), the temporal progression of corals appearing on a recovering reef does not follow a deterministic sequence (Rogers 1993), as would be expected under the facilitation and tolerance models of succession proposed by Connell \& Slatyer (1977).

Second, rather than reflecting differential sampling of a successional sequence differing in time since the last disturbance, the site effects could reflect the interplay between a spatio-temporal mosaic of disturbances and a temporally dynamic supply of coral larvae varying in quantity and relative species composition. In this construct, coral community structure at each site is determined by the taxonomic composition of the larval assemblages reaching disturbed areas, and thereafter, the newly recruited corals interfere with the capacity of subsequently-arriving coral larvae to settle, metamorphose, and grow. This mechanism is the 'inhibition' model of succession described by Connell \& Slatyer (1977) (see also Sutherland 1974) and later described as 'priority effects' (Shulman et al. 1983) that are enjoying renewed attention (Chase 2010).

Assuming that deterministic succession following disturbances cannot account for the landscape-scale variation in coral reefs reported here, is there evidence supporting the inhibition/priority effects hypothesis? Although nothing is known about the extent to which the supply of coral larvae varies over time, the reproductive biology of corals suggests that species composition and relative abundances will vary within and among years. Pelagic coral larvae will, for example, be most abundant following the discrete breeding events characterizing most corals (Harrison 
\& Wallace 1990), and the taxonomic composition of larval assemblages will vary with the differing timing of reproduction among coral species (Harrison \& Wallace 1990). Furthermore, fecundity (as a cause of variation in larval supply) will differ among years varying in physical conditions, and be depressed in (or following) adverse years such as those in which bleaching occurs (Szmant \& Gassman 1990). The aforementioned factors suggest that coral recruits will vary in taxonomic composition depending on when settlement space is available. Settlement tiles on shallow reefs (5 to $6 \mathrm{~m}$ depth) in St. John show that the relative abundances of coral recruits vary within a year, with more poritids than agaricids from January to August and more agaricids than poritids from August to January (Green \& Edmunds 2011).

Further evidence of variation in coral recruitment comes from surveys of juvenile corals (i.e. $\leq 40 \mathrm{~mm}$ diameter) on reefs between Cabritte Horn and White Point (Edmunds 2013). The population density of juvenile corals pooled among taxa varied markedly from 1994 to 2011, and this trend was composed of asynchronous variations for the most common genera, each of which displayed repeated episodes of waxing and waning abundance (Edmunds 2013). Although identifying the causes of these trends is made difficult by the upper age limit of these small corals (i.e. 7 to

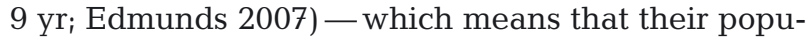
lation sizes are determined by multiple years of recruitment, growth, and mortality - nonetheless, the variation in population density is consistent with the hypothesis that recruitment varied among years and probably in dissimilar ways for multiple genera. Given the differences in the cover of coral genera among sites around St. John and St. Thomas, signs that coral recruitment varies among years are important, because this finding supports the possibility that the taxonomic identity of the corals recruiting to disturbed reefs will differ among years in which disturbances occur in different months. Variation in the first arrivals to a vacant community is a prerequisite for the inhibition/priority effects hypothesis to favor the formation of dissimilar communities among multiple sites (Connell \& Slatyer 1977).

In summary, the present study underscores the importance of identifying the causal agents of landscape-scale (i.e. over 20 to $200 \mathrm{~km}$ ) variation in coral reef community structure, with the inhibition/priority effects hypothesis as one possibility that might warrant attention. Long-term monitoring can provide a means to test this hypothesis, because the stochastic aspects of the inhibition/priority effects hypothesis predict shifts in generic composition of coral commu- nities following disturbances. In other words, the assembly rules for these communities will be flexible (sensu Hughes et al. 2012). It is also a research priority to elucidate the extent to which unique coral community assemblages affect trajectories of change in community structure, for this could provide important insights into conservation priorities for protecting coral reefs of unusual cover or species composition (Graham et al. 2014).

Acknowledgements. This research was funded by the US National Science Foundation through the Long Term Research in Environmental Biology (LTREB) program (grant DEB 08-41441) and was completed under a permit from the US National Park Service (VIIS-2011-SCI-0016). The work between White Point and Cabritte Horn is part of a longterm analysis that began in 1987 and has benefitted from the help of many people, including R. Boulon, C. S. Rogers, V. Powell, and S. Prosterman. I am grateful to the staff of the Virgin Islands Environmental Resource Station for making our stays enjoyable and productive, S. Crum of Ocean Runner Power Boat rentals for facilitating marine operations, and 3 anonymous reviewers who provided comments that improved an earlier draft of this paper. S. Dudgeon and M. Steele were generous with statistical advice. This is contribution number 215 of the marine biology program of California State University, Northridge.

\section{LITERATURE CITED}

Ateweberhan M, McClanahan TR, Graham NAJ, Sheppard CRC (2011). Episodic heterogeneous decline and recovery of coral cover in the Indian Ocean. Coral Reefs 30: $739-752$

Anderson MJ, Gorley RN, Clarke KR (2008) PERMANOVA+ for PRIMER: guide for software and statistical methods. PRIMER-E, Plymouth, UK

> Aronson RB, Precht WF (2000) Herbivory and algal dynamics on the coral reef at Discovery Bay, Jamaica. Limnol Oceanogr 45:251-255

Aronson RB, Precht WF (2001) White-band disease and the changing face of Caribbean coral reefs. Hydrobiologia 460:25-38

> Aronson RB, Precht W, Toscano M, Koltes KH (2002) The 1998 bleaching event and its aftermath on a coral reef in Belize. Mar Biol 141:435-447

Bellwood DR, Hughes TP, Folke C, Nyström M (2004) Confronting the coral reef crisis. Nature 429:827-833

$>$ Brown BE, Dunne RP (1980) Environmental controls of patch-reef growth and development. Mar Biol 56:85-96

Bruno JF, Selig ER (2007) Regional decline of coral cover in the Indo-Pacific: timing, extent, and subregional comparisons. PLoS ONE 2:e711

Bruno JF, Precht WF, Vroom PS, Aronson RB (2013) Coral reef baselines: how much macroalgae is natural? PeerJ PrePrints 1:e19v1

> Budd AF, Fukami H, Smith ND, Knowlton N (2012) Taxonomic classification of the reef coral family Mussidae (Cnidaria: Anthozoa: Scleractinia). Zool J Linn Soc 166: 465-529

Burman SG, Aronson RB, van Woesik R (2012) Biotic homo- 
genization of coral assemblages along the Florida reef tract. Mar Ecol Prog Ser 467:89-96

- Chase JM (2010) Stochastic community assembly causes higher biodiversity in more productive environments. Science 328:1388-1391

Chave J (2013) The problem of pattern and scale in ecology: What have we learned in 20 years? Ecol Lett 16:4-16

Clarke KR, Gorley RN (2006) PRIMER v6: user manual/tutorial. PRIMER-E, Plymouth

> Connell JH, Slatyer RO (1977) Mechanisms of succession in natural communities and their role in community stability and organization. Am Nat 111:1119-1144

> Côté IM, Gill JA, Gardner TA, Watkinson AR (2005) Measuring coral reef decline through meta-analyses. Philos Trans R Soc Lond B 360:385-395

> Done TJ (1982) Patterns in the distribution of coral communities across the central Great Barrier Reef. Coral Reefs 1:95-107

Done TJ (1999) Coral community adaptability to environmental change at the scales of regions, reefs and reef zones. Am Zool 39:66-79

> Doney SC, Fabry VJ, Feely RA, Kleypas JA (2009) Ocean acidification: the other $\mathrm{CO}_{2}$ problem. Annu Rev Mar Sci 1:169-192

Edmunds PJ (2007) Evidence for a decadal-scale decline in the growth rates of juvenile scleractinian corals. Mar Ecol Prog Ser 341:1-13

- Edmunds PJ (2013) Decadal-scale changes in the community structure of coral reefs of St. John, US Virgin Islands. Mar Ecol Prog Ser 489:107-123

Edmunds PJ, Elahi R (2007) The demographic of a 15-year decline in cover of the Caribbean reef coral Montastraea annularis. Ecol Monogr 77:3-18

Endean R (1973) Destruction and recovery of coral reef communities. In: Jones OA, Endean R (eds) Biology and geology of coral reefs, Vol 3. Academic Press, New York, NY, p 215-254

Friedlander AM, Jeffrey CFG, Hile SD, Pittman SJ and others (2013) Coral reef ecosystems of St. John, U.S. Virgin Islands: spatial and temporal patterns in fish and benthic communities (2001-2009). NOAA Technical Memorandum 152, Silver Spring, MD

> Glynn PW (1993) Coral reef bleaching: ecological perspectives. Coral Reefs 12:1-17

Graham NAJ, Cinner JE, Norstrom AV, Nystrom M (2014) Coral reefs as novel ecosystems: embracing new futures. Curr Opin Environ Sustain 7:7-14

> Green DH, Edmunds PJ (2011) Spatio-temporal variability of coral recruitment on shallow reefs in St. John, US Virgin Islands. J Exp Mar Biol Ecol 397:220-229

> Green DH, Edmunds PJ, Carpenter RC (2008) Increasing relative abundance of Porites astreoides on Caribbean reefs mediated by an overall decline in coral cover. Mar Ecol Prog Ser 359:1-10

Harrison PL, Wallace CC (1990) Reproduction, dispersal and recruitment of scleractinian corals. In: Dubinsky Z (ed) Ecosystems of the world. Elsevier Science Publishers, New York, NY, p 133-207

> Hoegh-Guldberg O, Mumby PJ, Hooten AJ, Steneck RS and others (2007) Coral reefs under rapid climate change and ocean acidification. Science 318:1737-1742

Hughes TP, Graham NAJ, Jackson JBC, Mumby PJ, Steneck RS (2010) Rising to the challenge of sustaining coral reef resilience. Trends Ecol Evol 25:633-642

Hughes TP, Bellwood DR, Baird AH, Brodie J and others
(2011) Shifting base-lines, declining coral cover, and the erosion of reef resilience: comment on Sweatman et al. (2011). Coral Reefs 30:653-660

Hughes TP, Baird AH, Dinsdale EA, Moltschaniwskyj NA and others (2012) Assembly rules of reef corals are flexible along a steep climatic gradient. Curr Biol 22:736-741

> Jackson JBC (1997) Reefs since Columbus. Coral Reefs 16: 23-32

Jackson J, Donovon M, Cramer K, Lam YYV (2014) Status and trends of Caribbean coral reefs: 1970-2012. Global Coral Reef Monitoring Network, International Union for the Conservation of Nature, Gland

Karlson RH, Hurd LE (1993) Disturbance, coral reef communities, and changing ecological paradigms. Coral Reefs 12:117-125

Kohler KE, Gill SM (2006) Coral Point Count with Excel extensions (CPCe): a Visual Basic program for the determination of coral and substrate coverage using random point count methodology. Comput Geosci 32:1259-1269

Lessios HA, Robertson DR, Cubit JD (1984) Spread of Diadema mass mortality through the Caribbean. Science 226:335-337

> Levin SA (1992) The problem of pattern and scale in ecology. Ecology 73:1943-1967

- Mittelbach GG, Steiner CF, Scheiner SM, Gross KL and others (2001) What is the observed relationship between species richness and productivity? Ecology 82:2381-2396

> Mumby PJ, Steneck RS, Hastings A (2013) Evidence for and against the existence of alternate attractors on coral reefs. Oikos 122:481-491

Parmesan C, Yohe G (2003) A globally coherent fingerprint of climate change impacts across natural systems. Nature 421:37-42

Ricklefs RE (1990) Ecology. WH Freeman, New York, NY

> Rogers CS (1993) Hurricanes and coral reefs: the intermediate disturbance hypothesis revisited. Coral Reefs 12: 127-137

Rogers CS, Miller J (2006) Permanent 'phase shifts' or reversible declines in coral cover? Lack of recovery of two coral reefs in St. John, US Virgin Islands. Mar Ecol Prog Ser 306:103-114

Rogers CS, Miller J, Muller EM, Edmunds P and others (2008) Ecology of coral reefs in the US Virgin Islands. In: Riegl BM, Dodge RE (eds) Coral reefs of the USA. Dania, Springer, p 303-374

Sandin SA, Smith JE, DeMartini EE, Dinsdale EA and others (2008) Baselines and degradation of coral reefs in the northern Line Islands. PLoS ONE 3:e1548

Schutte VG, Selig ER, Bruno JF (2010) Regional spatiotemporal trends in Caribbean coral reef benthic communities. Mar Ecol Prog Ser 402:115-122

Shulman MJ, Ogden JC, Ebersole JP, McFarland WN and others (1983) Priority effects in the recruitment of juvenile coral reef fishes. Ecology 64:1508-1513

Smith TB, Kadison E, Henderson L, Gyory J and others (2011) The United States Virgin Islands Territorial Coral Reef Monitoring Program. Year 11 Annual Report, Version 1

Smith TB, Brandt ME, Calnan JM, Nemeth RS, Blondeau J and others (2013) Convergent mortality responses of Caribbean coral species to seawater warming. Ecosphere 4:art87

Sutherland JP (1974) Multiple stable points in natural communities. Am Nat 108:859-873

Sweatman H, Delean S, Syms C (2011) Assessing loss of 
coral cover on Australia's Great Barrier Reef over two decades, with implications for longer-term trends. Coral Reefs 30:521-531

Szmant A (2001) Introduction to the special issue of Coral Reefs on 'Coral reef algal community dynamics'. Coral Reefs 19:299-302

Szmant A, Gassman NJ (1990) The effects of prolonged 'bleaching' on the tissue biomass and reproduction of the reef coral Montastrea annularis. Coral Reefs 8: $217-224$

Editorial responsibility: Charles Birkeland,

Honolulu, Hawaii, USA
Vermeij MJ, Sandin SA (2008) Density-dependent settlement and mortality structure the earliest life phases of a coral population. Ecology 89:1994-2004

Wiens JA (1989) Spatial scaling in ecology. Funct Ecol 3: 385-397

Woodley JD, Chornesky EA, Clifford PA, Jackson JBC and others (1981) Hurricane Allen's impact on Jamaican coral reefs. Science 214:749-755

Zar JH (2010) Biostatistical analysis. Pearson, Upper Saddle River, NJ

Submitted: December 23, 2013; Accepted: May 30, 2014

Proofs received from author(s): August 15, 2014 